\title{
The impact and importance of new technologies in business development in context of economic diversity
}

\author{
Oana-Georgiana CIOBANU \\ University "Stefan cel Mare", Suceava, Romania \\ Daniela Mihaela NEAMT,U \\ University "Stefan cel Mare", Suceava, Romania \\ oana.ciobanu91@yahoo.com
}

\begin{abstract}
In a globalized world, led and connected by and through technology, gadgets and perpetual and intense technological development, the business environment and the trajectory travelled by entrepreneurs in the process of creation and development of a business, becomes more and more challenging and complex. Continuous innovation has become mandatory and "adaptability" became the keyword for the success of any entrepreneurial actions. In this socio-economic context, an organization must find, through entrepreneurs or managers, the courage to face the uncertainty and be always prepared to adopt radical solutions, so that, can provide sustainability of the business through competitiveness. The purpose of this research started from the need for adaptability and flexibility of the Romanian entrepreneurial environment to the trends in the digital era, in order to maintain the level of competitiveness and to develop sustainably. The objective of this scientific approach is to conduct a qualitative comparative analysis relating to the importance and the impact of new technologies in the development and sustainability of a business. The comparison will be made through the eyes of two main categories of actors in the creation and development of a business namely entrepreneurs and managers from two consecutive generations - generation $X$ (born between 1965 and 1980) and generation Y (born between 1980 and 1995). The methodology used in this study is qualitative research through focus group method, and it aims to be highlighted the changes occurred in leadership and management style of a business/organization, by observing and comparing the two generations' attitudes towards change, towards new, towards the digital component, and the intent of the use of new technologies, and more than that, their impact on the management style.
\end{abstract}

Keywords: sustainable entrepreneurship, new technologies, innovation, sustainable development, generation $\mathrm{Y}$, generation $\mathrm{X}$.

\section{Introduction}

In the past 50 years, we have witnessed the basic changes of the world economy on all its sides. These changes happened so fast and had an intensity so strong that economic agents, public authorities and society faced on the one hand with the challenges of adapting and on the other hand with the collapse of the values systems incompatible with the realities of the present world. So, today we are witnessing a world in which, trade and capital flows between countries have multiplied so much, that were to become reality the phrase 'globalization of the world economy'. The phenomenon of globalization, represents a subject that has been on the attention of researchers and have been written countless articles and studies, because rewrite the old perceptions of economic, political, social environments which conducted the world for decades. In this context, contemporary business environment has become an increasingly more developed and complex environment, and IT domain has contributed greatly to this due to multiple cycles of 
innovation that has experienced over time, responding almost immediately to the needs of the company or creating them.

As a consequence of the passage of time and changes, new generations began to have a decisive role due to the different characteristics, different skills, they were grown and adapted to the era of digitalization and technology. These new generations, for example generation $Y$, compared to previous generations brought with them changes for the labor market, for entrepreneurial and management trends, for consumerist trends, or production techniques. Generation Y is the generation that was born between 1980-1995, entered on the labor market since 2000 and started the process of continuous innovation and adoption of technology. They are interested in measures of social involvement of the companies where they work or they hold. The work style is characterized by a dependency on permanent connection to the internet through cutting-edge technology and likes to contribute to the development of the company through innovative ideas.

These new features have begun to be reflected also in the entrepreneurial environment. A large proportion of enterprises have started to use systems based on technology and internet to increase the efficiency, to decrease operating costs and increase the ability to operate in real-time data and information between various platforms with partners from every corner of the world. Thus, many organizations reprojects and restructures business processes, through investment in technologies such as cloud computing, information systems for economic analysis and decision support or social networks.

Our research started from the necessity of observing and comparing these changes, both in business, in leadership styles and management, but also in resource management of a company from one generation to another, having as main factor of change: new technologies. But, in a globalized economy characterized by dependence on technology and internet and a transition between two generations, which should be the limit for the adoption of change and technology, which should be the predominant characteristics to define sustainable business?

\section{Literature review}

The entrepreneur first appeared in the writings of Cantillon (1680-1734). Cantillon recognized three classes of economic agents: landowners, entrepreneurs and employees. Cantillon's entrepreneur is someone who exercises business engagements in the face of uncertainty.

Marshall portrays the capacity of 'superintendence'. This superintendent sorts out the creation in a firm. Marshall connected a more critical part to business people, 'the pioneers of new paths' (Marshall, 1961), than whatever other neo-classical theorist. Knight and Schumpeter recognized this administrative or director part from the atributes of the 'entrepreneur'. Since the compositions of Knight, it is standard to recognize between hazard and vulnerability. The last is remarkable and uninsurable.

Innovation based entrepreneurship, nevertheless, postures challenges to portray business person's activities utilizing the discovery view; it really challenges the comprehension of entrepreneurship as a procedure that has 'arrange/plan' and 'action' as distinct and consecutive activities (Baker et al. 2003).

In opposition with environments that are very much characterized utilizing the discovery view, technology-based entrepreneurship is remainder with instability, not just 
in the exploitation ways of a given technology (Gruber et al. 2008) but also in the early steps of the technological opportunity conceptualization (McMullen \& Shepherd 2006). At this level, potential technology-based thoughts stay undiscovered as the entrepreneur battles to win a social approval (Shepherd et al. 2007) that would switch the subjective thought into a goal.

We are witnessing therefore the emergence of new markets, industries, companies, working practices which together form a new kind of economy namely digital economy or creative economy. It is characterized by digitization and the intensive use of information and communication technologies, coding knowledge, exchange of information and different ways of organizing production or human resources.

\section{Scope and objectives of research}

The purpose of this research started from the need for adaptability and flexibility of the Romanian entrepreneurship to the trends in the digital era, in order to maintain the level of competitiveness and to develop sustainably.

The objective of this scientific approach is to conduct a qualitative comparative analysis relating to the importance and the impact of new technologies in the development and sustainability of a business. The comparison has been made through the eyes of two main categories of actors in the creation and development of a business namely entrepreneurs and managers from two consecutive generations - generation X (born between 1965 and 1980) and generation Y (born between 1980-1995). It aims to be highlighted the changes occurred in leadership and management style of a business, by observing and comparing the two generations' attitudes towards change, towards new, towards the digital component, and the intent of the use of new technologies, and more than that, their impact on the management style.

Following the previously mentioned directions of research and summarizing current research intentions were formulated following assumptions:

- digital literacy and reliance on technology in modern society are applicable and are juxtaposed in businesses.

- young entrepreneurs or managers are more likely to use new technologies in businesses they run towards entrepreneurs and managers of generation $\mathrm{X}$.

- new technologies bring business benefits if they are used.

\section{Research methodology}

The methodology used in this study is qualitative research through focus group method. Considering that the theme explored is a subject of general interest we have considered appropriate a group qualitative method because of the: discussion;

- opportunity to obtain focused and exploratory data on the subject under

- interaction within a group with synergistic effects which have as a product superior results in comparison with the results of personal interviews;

- possibility to obtain exploratory information on the chosen theme for search;

- construction of hypotheses and preparing quantitative data collection.

The analysis of data obtained from this focus groups, was achieved through classical method of comprehensive analysis. This ensures a high degree of reliability and validity of 
final results, without having to modify the specific character of 'understanding and explanation' offered by the qualitative methodology. This mode of analysis, allows, the passage from the rational to highlight the repressed attitudes, behaviors, moods of respondents' motivations. The results thus obtained, provides, an in-depth analysis, a detailed radiograph of the research objectives. Interpretation of the data collected, as a result of the application of this method, have to be treated as assumptions, as descriptions of situations in certain context, and as premises for future quantitative research.

Sampling of participants did not put emphasis on statistical representativeness rules, but rather on theoretical sampling rules, with tilting towards the overall objectives of the research and the dominant characteristics of hypothetical pattern of the research.

Table 1. Focus group structure

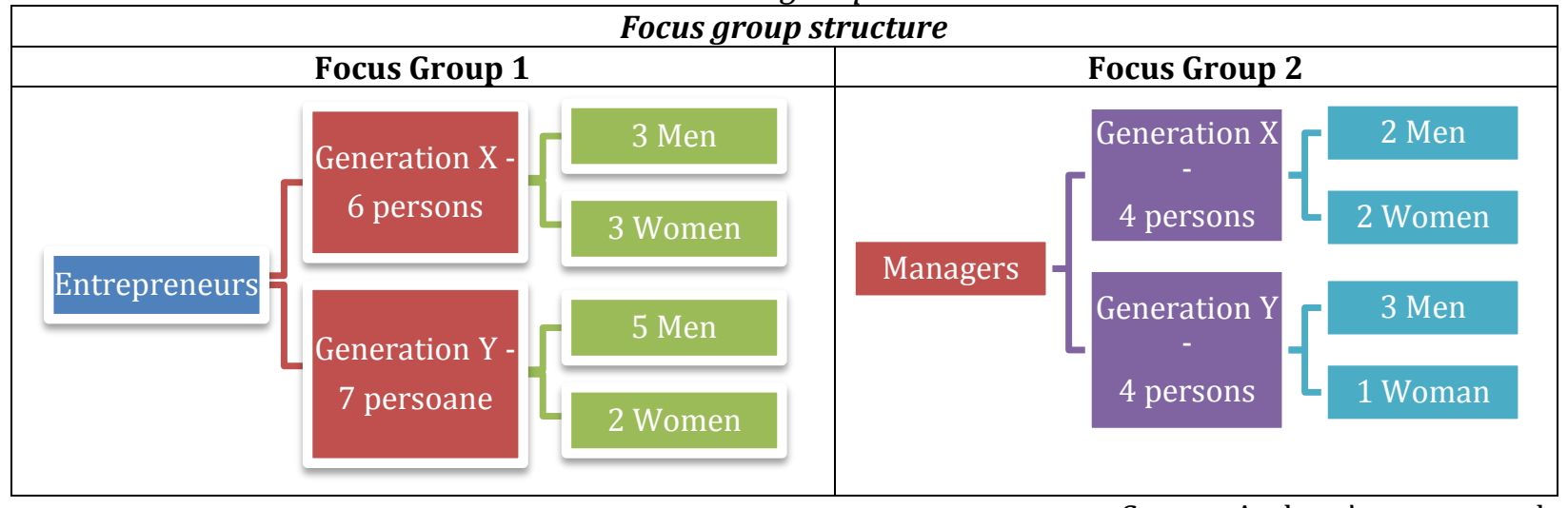

Source: Authors' own research.

There were two focus groups conducted in April 2016, with a maximum duration of $1 \mathrm{~h} 30$ minutes, based on a structured interview. This was divided into 4 parts namely:

-1 opening question;

-3 introductory questions;

-3 key questions;

-1 closure question - and includes a total of 8 questions.

The structure of the focus groups was made containing members of the representatives of the two groups of actors: entrepreneurs and managers belonging to generations $\mathrm{X}$ and $\mathrm{Y}$. In total, they were invited 16 representatives of each category, but they have responded to our invitation only 13 entrepreneurs and 8 managers according to the Table 1. and representation of participants from Table 2.

Table 2. The Matrix of respondents

\section{The Matrix of respondents}

Entrepreneurs

\begin{tabular}{|c|c|c|c|c|c|}
\hline \multicolumn{3}{|c|}{ Generation $X$} & \multicolumn{3}{c|}{ Generation $Y$} \\
\hline Gender & Field of activity & $\begin{array}{c}\text { Experience in } \\
\text { the field }\end{array}$ & Gender & Field of activity & $\begin{array}{c}\text { Experience in } \\
\text { the field }\end{array}$ \\
\hline
\end{tabular}




\begin{tabular}{|c|c|c|c|c|c|}
\hline Man & Commerce & 15 years & Man & Marketing digital, & 6 years \\
\hline Man & $\begin{array}{c}\text { Service and } \\
\text { programming } \\
\text { woodworking } \\
\text { machinery }\end{array}$ & 25 years & Man & $\begin{array}{l}\text { Tourism and } \\
\text { marketing, }\end{array}$ & 2 years \\
\hline Man & $\begin{array}{l}\text { Industrial and IT } \\
\text { automation, } \\
\text { mechanic, } \\
\text { pneumatic }\end{array}$ & 20 years & Man & $\begin{array}{c}\text { Business consulting, } \\
\text { international } \\
\text { services }\end{array}$ & 11 years \\
\hline Woman & Real estate & 20 years & Man & Services & 9 years \\
\hline Woman & $\begin{array}{c}\text { Thermal power } \\
\text { plants }\end{array}$ & 19 years & Man & Services & 10 years \\
\hline Woman & Services & 10 years & Woman & Tourism & 1 year \\
\hline & & & Woman & Health & 12 years \\
\hline \multicolumn{6}{|c|}{ Managers } \\
\hline \multicolumn{3}{|c|}{ Generation X } & \multicolumn{3}{|c|}{ Generation $Y$} \\
\hline Gender & Field of activity & $\begin{array}{c}\text { Experience in } \\
\text { the field }\end{array}$ & Gender & Field of activity & $\begin{array}{c}\text { Experience in } \\
\text { the field }\end{array}$ \\
\hline Man & $\begin{array}{l}\text { Consultancy, } \\
\text { Training }\end{array}$ & 7 years & Man & Woodworking, & 1 year \\
\hline Man & Services & 10 years & Man & IT & 7 years \\
\hline Woman & $\begin{array}{l}\text { Tailoring, } \\
\text { embroidery, }\end{array}$ & 1 year & Man & $\begin{array}{c}\text { Entrepreneurship, } \\
\text { Social Economy }\end{array}$ & 8 years \\
\hline Woman & $\begin{array}{l}\text { Production of } \\
\text { furniture }\end{array}$ & 30 years & Woman & Economics & 1 year \\
\hline
\end{tabular}

Source: Authors' own research.

\section{Research methodology}

\section{a) The opening question:}

Following the introduction made by moderator, according to which was outlined topic of discussion, new technologies have assigned the following meanings:

- technology that radically modify how something is produced or realized, especially by saving labor through automation or computerization (http://www.oxforddiction aries.com);

- more broadly, adopted meaning of 'new technologies' in this study, it is represented by IT solutions ranging from the use of cloud computing platforms (ensemble of distributed computing services, applications, access to information and data storage, without the user needing to know the position of the physical location and configuration of systems providing these services), economic systems represented by applications in operational or managerial domains (ERP systems - system of integrated management of business 
processes or derivatives / components thereof as CRM - system of customer relationship management, WMS - warehouse management system, Business Intelligence (BI) - systems for identifying, extracting and analyzing available data in a company, systems whose purpose is to provide real support for business decisions etc.) up to forms of electronic commerce (through on-line stores, dedicated platforms, etc.) or exchange of information using the Internet (hubs, dedicated sites/blogs, forums etc.). The importance of new technologies in support of business was evaluated positively, and their impact on business results was recognized by most participants in the focus groups 'We use frequently such instruments in our business'. If among managers, only one male participant from generation Y stated that, still, he did not use these instruments for purposes of business, but certainly it would use, among entrepreneurs responses were varied, having for each generation one male participant who has admitted that he did not use the new technologies in the management of his business, and for the generation $\mathrm{X}$ filling even that 'did not give so much importance to these instruments'. We note, however, that the level of knowledge, inclination and openness to new technologies is quite high among both generations, regardless of gender. According with this, we emphasize an essential factor that we can take into account, namely, the level of education completed by participants, which is from university bachelor's and master cycles till the $\mathrm{PhD}$ or postdoctoral studies.

\section{b) Introductory questions}

Regarding the allocation of funds for investment in new technologies, both, generation $\mathrm{X}$ and generation $Y$ showed an awareness of the importance of results obtained using these digital methods to support and develop business. Of the total 21 participants of the two focus groups organized, a number of 20 people responded affirmatively, namely that it would invest in such measures, only one man belonging to the group of entrepreneurs from generation $\mathrm{X}$ being reluctant. Regarding of the trust on these modern tools, as a result of structuring and analyzing of the responses of people in focus groups organized, we have noticed some interesting aspects highlighted on Table 3.

Table 3. Percentage of trust in new technologies by gender, generation and ocuppation

\begin{tabular}{lclll}
\hline & \multicolumn{2}{c}{ Entrepreneurs } & \multicolumn{2}{c}{ Managers } \\
\hline Men & $01-25 \%-1^{*}$ & $01-25 \%-1 \mathrm{p}$ & $51-75 \%-2 \mathrm{p}$ & $51-75 \%-1 \mathrm{p}$ \\
Total = 13 persons ) & $26-50 \%-1 \mathrm{p}$ & $51-75 \%-3 \mathrm{p}$ & & $76-99 \%-2 \mathrm{p}$ \\
& $51-75 \%-1 \mathrm{p}$ & $100 \%-1 \mathrm{p}$ & & \\
& Total $: 3$ & Total $: 5$ & Total $: 2$ & Total $: 3$ \\
Women & $76-99 \%-2 \mathrm{p}$ & $26-50 \%-1 \mathrm{p}$ & $51-75 \%-1 \mathrm{p}$ & $51-75 \%-1 \mathrm{p}$ \\
(Total = 8 persons ) & $100 \%-1 \mathrm{p}$ & $100 \%-1 \mathrm{p}$ & $76-99 \%-1 \mathrm{p}$ & \\
& Total : 3 & Total $: 2$ & Total: 2 & Total $: 1$ \\
& Generation X & Generation Y & Generation X & Generation Y \\
\hline
\end{tabular}

Source: Authors' own research.

p*-person

The group of male entrepreneurs from generation $\mathrm{X}$ grants a lower trust on new technologies towards female entrepreneurs group of that same generation, also the last group gives greater trust on these tools unlike the same group of participants on this interview from generation $Y$.

Among managers, we can observe that trust on new technologies of the male respondents is above average in both generation $\mathrm{X}$ and generation $\mathrm{Y}$. The same phenomenon can be observed in the case of female respondents. 
Therefore, as we can see in the Figure 1., regarding the overall responses obtained from this question, we note that the level of confidence in business management using these tools is predominantly increased, 9 of respondents giving a level of confidence in new technologies between $51-75 \%$, followed by a number of 5 persons in the range of $76-99 \%$, and depending on the area where they are operating a number of 3 person paying $100 \%$ confidence on digital solutions from the total of 21 participants. We emphasize that these statistics may not be considered as representative for the entrepreneurs or managers from Suceava, due to the low number of respondents and the chosen research method, but can be taken as a benchmark in future quantitative research.

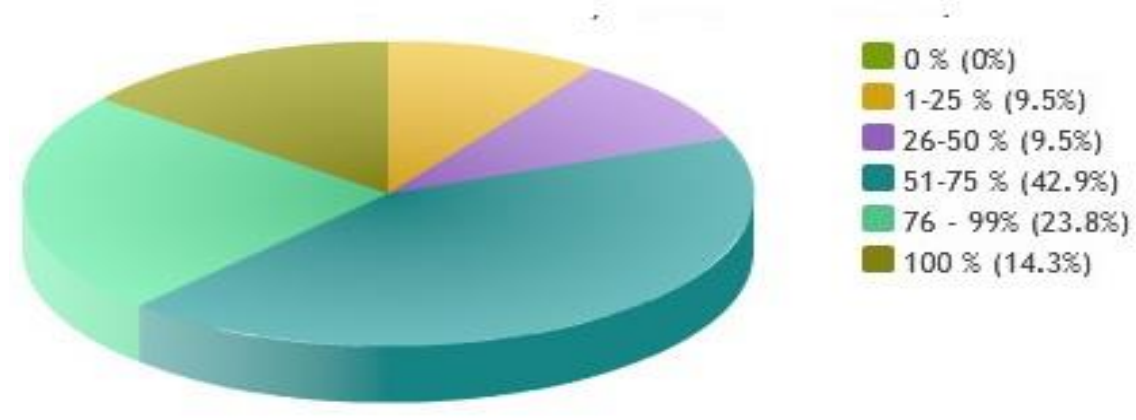

PICBE | 704

Figure 1. Diagram of trust in new technologies (\%)

Source: Authors' own research

Among the methods listed above in defining new technologies, a greater relevance in the management and development of a business and without which it would not be possible a fair and complex management in the current socio-economic context, managers and entrepreneurs have responded and have chosen within the framework of the debate, as being the exchange of information using the Internet (hubs, dedicated sites / blogs forums etc.), e-commerce (online stores, dedicated platforms, etc.), and ERP systems-integrated management system of business processes.

Thus, it can be concluded after this series of introductory questions that both, members of generation $\mathrm{X}$ and generation $\mathrm{Y}$, included in this research were aware of the role and importance of new technologies in the success of a competitive business on the market.

\section{c) Key questions}

Deepening the discussion on the edge of the importance and impact of new technologies in the management, control and development of a business, entrepreneurs and managers have been asked who is the person in their company to whom it would be given the task of using new technologies, and the answers have not delayed. Within the focus group organized with entrepreneurs, they brought different answers. The group of entrepreneurs belonging to generation $Y$, proposed variants that are in close proximity starting even from themselves, 'I am the person in charge of this component', 'I would personally handle it at first, then I'd nominate someone', 'I think that first of all, as administrator, I should learn to manage this resource to find it exactly worth and fold it in my field of activity prior to delegate this task', till delegating the task to manager, where there is one, or even an entire team destined for this purpose, 'Accountant, a recruiter and a team leader', however, remarking that primarily is target the management team of the company. Instead, the trend of entrepreneurs from 
generation $\mathrm{X}$, it is to delegate this task to people with specific expertise, 'I hired a person dedicated to this post - IT specialization', or through the young employees, 'now, most all employees who have completed college fairly recently, know how to use the technique, I'd delegate this task for easier utilities to one of them, and for the most sophisticated I would hire a specialized firm '.

Interestingly, in the focus group held with managers the answers were similar, keeping this trends. Generation X managers have mapped this task is the responsibility of specialized persons, in particular the IT department, 'a person skilled in this area', or to the younger generation, 'a young, dynamic person with thorough knowledge in the IT field willing to get involved in what is doing', while generation Y managers have that task in their care, or nominated it to the management team. Both entrepreneurs and managers of the two generations have agreed, however, that their use is in need of training, depending on the complexity of information systems, 'Any new technology needs training', 'Certainly it requires a training for faster and detailed understanding', 'Always formation and training must prevail in a business, to keep abreast of market dynamics and society at macro level. Not only for the use of new technologies but also to shape the image of open minded staff! All the factors are important for the development of business environment starting with investment in human resources and then technologies... eventually, the new technologies are launched and created by the human brain!' assert an entrepreneur of generation X with 20 years of experience in the field. Another general trend applied to both focus groups, regardless of generation is that women prefer to get personally involved in adapting new technologies even if delegate this task to an employee, while men tend to place this task forward. The next question, sparked controversy and a constructive debate, and was that relating to new technologies versus human resource. It is opportune, therefore, replacing human resource with new technologies? Within the entrepreneurs focus group opinions have been splited. In terms of generation Y respondents, some of them considered that new technologies can replace human resource 'I have already given up some of the staff because it was not profitable to keep them, their work couldn't give justification', 'Yes, because it is more effective', others, depending on the domain of work considered as 'optimum solution within a company is combining the two, of human resource with new technologies, to benefit from an ideal result', ' Depends on whether it brings enough yield ', and others have asserted that new technologies cannot replace human resource arguing that 'New technologies can modify indeed workloads or job description, but human resource replacement is an option with extreme consequences not just favorable on long-term at social level', or as 'because in the field in which I activate human resource represents a key factor in business success.' Among the participants of generation Y on the discussion, has outlined a majority response, according to which human resources can be replaced with new technologies, arguing the fact that 'removes human error', but still with some restraint, using expressions such as 'where it is possible' or 'Yes, but with some extent'. In the group of managers responses were similar. The situation of the adoption of new technologies, in order to obtain the company's sustainability relevant was the following question: 'If you have already adopted new technologies what are the effects of their use on developing your company's sustainability? If you have not yet used the new technologies do you think that their adoption would have a favorable effect on the control and management functions on development of your company? 
Effects of the use of new technologies on the control, management and development of a company

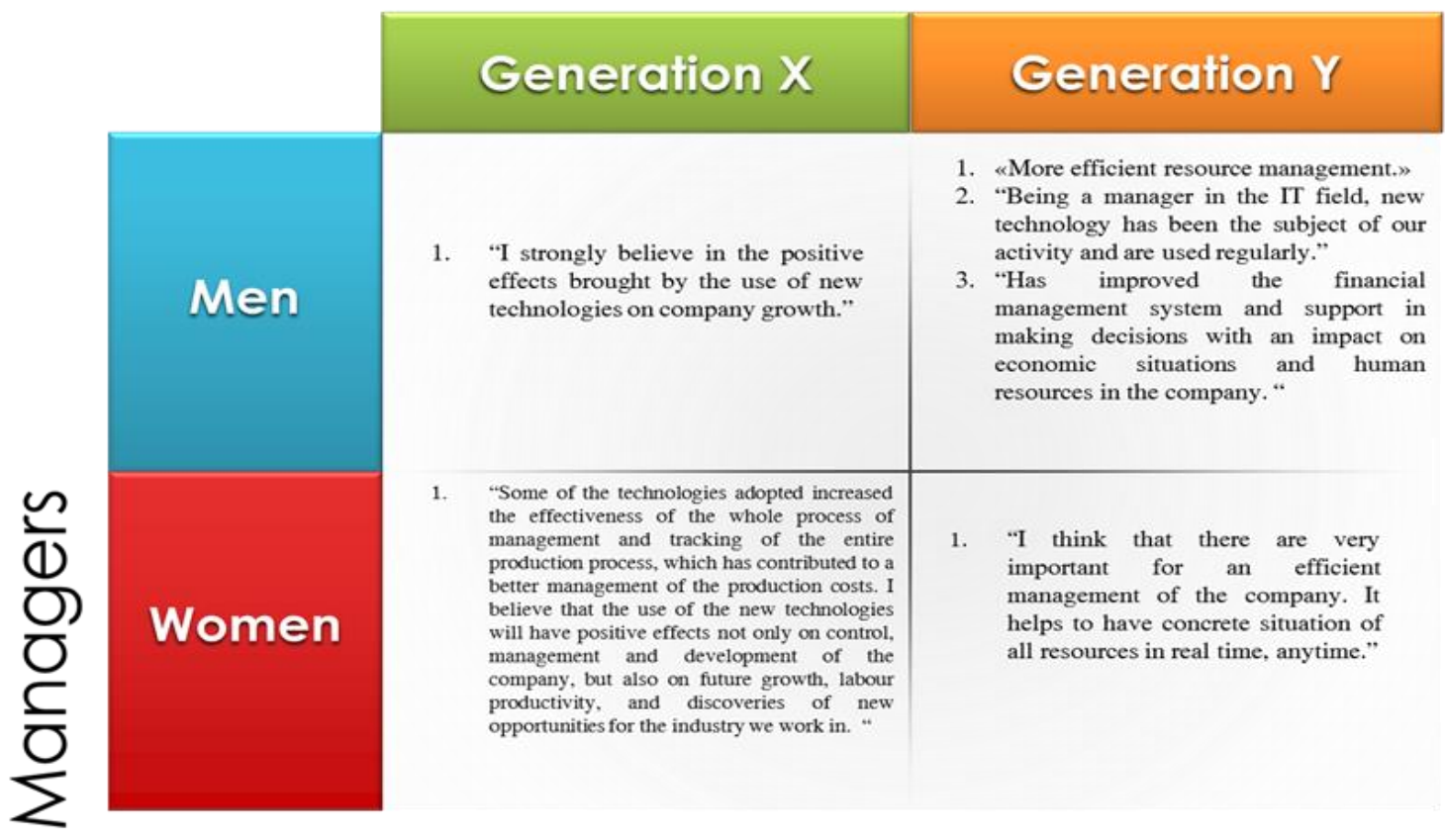

Figure 2. Effects of new technologies on the control, management and development of a company in the perspective of managers

Source: Authors' own research.

As we can see, in Figure 2. and Figure 3., both managers and entrepreneurs, responded that they have positive effects in the more efficient management of resources, in improving financial management system and the role of support in making decisions with an impact on economic situations and human resources in the company and in connecting in real time with all your resources. 


\section{Effects of the use of new technologies on the control, management and development of a company}

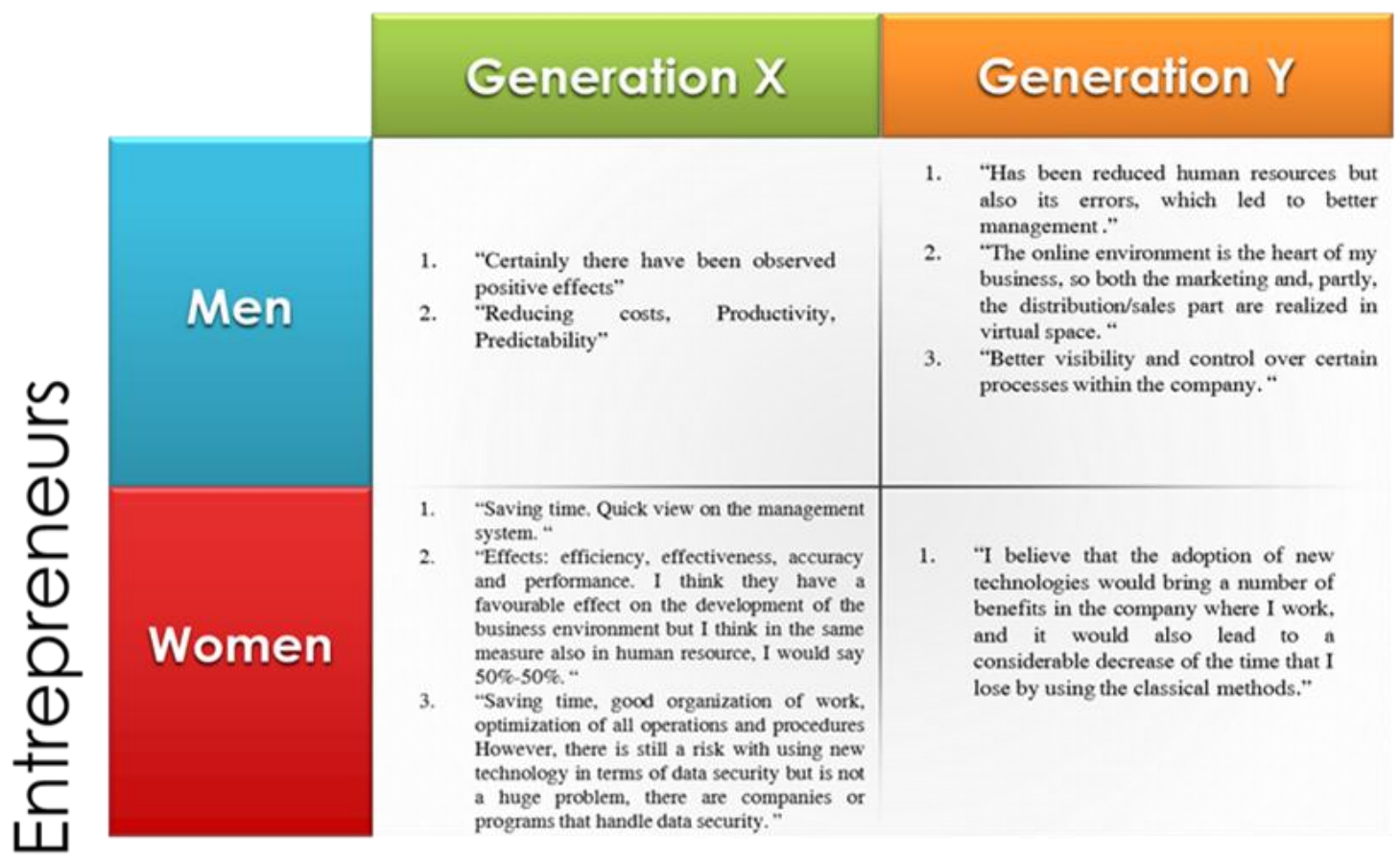

PICBE | 707

Figure 3. Effects of new technologies on the control, management and development of a company in the perspective of entrepreneurs

Source: Authors' own research.

\section{d) Concluding question}

The need for the use of technology in the control, development and support of business is a real need or an artificial created need (hyper-appreciated), derived from the society's dependence on the 21st century? Can a company be successful in the age of digitalisation unadapting to the technological changes that are happening, and using only traditional methods of production / management? It was drawn or can be drawn today a limit where companies should stop when adopting new technologies?

This problem, has created a very interesting scene of debates, both in the focus group intended for entrepreneurs and also for managers. Opinions were divided according to age and especially the field of activity. Entrepreneurs supported the idea of the need to use new technologies, but up to a certain point.When there is a need to take a logical and objective decision or perhaps emotional, new technologies may do not; they believe that there is no progress without adapting to the new. Should be merged almost seamlessly both conventional methods and the current ones. Not everything that is old is not good...you need a seventh sense to merge them in order to be successful! An entrepreneur should have it because not all people are created to be entrepreneurs! If you do not feel business, you don't have specific preparation, and you don't have skills, in vain you have new technologies.' Managers have expressed their views regarding the theme addressed by stating that: 'There are companies that do not use advanced production technologies and do 
not pursue this. Example: the textile industry that aims to come on the market with handmade clothes gives them an added value and excitement to holders'; 'I believe that the use of technology and new solutions within a company is absolutely necessary and almost mandatory nowadays, and managers of companies must adapt to these new technologies to correctly positioning the company in a constantly changing market and a business environment that is in continuous development. It was very important that the technology to adapt to current conditions, but should not be exaggerated. We don't have to use technology where it is not the case, nor to replace our human resources instead of technology if it lowers the quality of the products or relevant services provided. '

\section{Conclusion}

Advances in information and communication technologies are found in changing the way we live, wherever we look. The realities of the economic, social and education dimensions bring into light the need for growth and development of a new generation of entrepreneurs with characteristic skills such as responsibility, spontaneity, adaptability, flexibility, initiative and management spirit. These skills are essential for the profile of an entrepreneur; they generate specific skills in identifying and implementing appropriate strategies for economic efficiency. During a period of significant changes in the worldwide economy, the creation and improvement of high-development, innovation firms have been perceived as key factors for expanding national (and local/regional) wealth and competitiveness.

In this study, we intended to do a preliminary research through a qualitative comparative analysis relating to the importance and the impact of new technologies in the development and sustainability of a business. Among the aspects that have captured our attention, are the following one: male group of entrepreneurs from generation $\mathrm{X}$, attaches a lower trust to new technologies towards female entrepreneurs group of the same generation, latest group also grants greater confidence of these tools despite the same group of respondents from generation $\mathrm{Y}$ and that managers are more confident regardless of generation or gender in the use of new technologies than entrepreneurs.

A concluding remark of the latter aspect might be that, when it comes about the use of available resources, it is met a higher retention among entrepreneurs than managers, interfering the subjective factor with that the management process is viewed. Furthermore, another remark we do, is that more rational side of the men, shall say the word they being slightly more reluctant when it comes to innovation in any aspect and in any form would present, without a test, unlike women, who embrace this phenomenon easier. Also, when it comes about replacing human resources with new technologies opinions are different from one to another, depending on the most of the domain.It was seen that participants from generation $\mathrm{Y}$ are more likely to do not give up on human resources instead of technology and generation $\mathrm{X}$ despite assumptions are on the opinion that technologies can replace humans but the best option is to combine those two. So we can say that from those three assumptions two of them was confirmed.

As a final conclusion, we can say that, during a period of significant changes in the worldwide economy, the creation and improvement of high-development, innovation firms have been perceived as key factors for expanding national (and local/regional) wealth and competitiveness. 


\section{References}

Acs, Z.J., Carlsson, B., Karlsson, Ch. (1999). The Linkages Among Entrepreneurship, SMEs and the Macroeconomy, in Z. J. Acs, B. Carlsson and Ch. Karlsson (eds.), Entrepreneurship, Small and Medium-Sized Enterprises and the Macroeconomy, Cambridge, U.K.: Cambridge.

Alvarez, S.A., Barney, J.B. (2007). Discovery and creation: alternative theories of entrepreneurial action. Strategic Entrepreneurship Journal, 1(1-2), 11-26

Audretsch, D.B., Thurik, A.R. (1998). The Knowledge Society, Entrepreneurship and Unemployment, Research Report 9801/E, Zoetermeer: EIM.

Baker, T., Miner, A.S., Eesley, D.T. (2003). Improvising firms: bricolage, account giving and improvisational competencies in the founding process, Research Policy, 32(2), 255276

Burduş, E. (2000). Managementul schimbării organizaţionale. București: Economica.

Carree, M.A., Thurik, A.R. (1999). Industrial Structure and Economic Growth, in D.B. Audretsch and A.R. Thurik (eds.), Innovation, Industry Evolution and Employment, Cambridge, U.K.: Cambridge University Press, forthcoming.

Dew, N. et al. (2010). On the entrepreneurial genesis of new markets: effectual transformations versus causal search and selection. Journal of Evolutionary Economics,b 21(2), 231-253.

Drucker, P.F. (1985). Innovation and Entrepreneurship; Practice and Principles, New York: Harper and Row.

Giones, F., Zhou, Z., Miralles, F., Katzy, B.A. (2012). Constructivist Approach for Technologybased Entrepreneurship. The XXIII ISPIM Conference - Action for Innovation:Innovating from Experience - in Barcelona, Spain on 17-20 June.

Gruber, M., MacMillan, I.C., Thompson, J.D. (2008). Look Before You Leap: Market Opportunity Identification in Emerging Technology Firms. Management Science, 54(9), p.1652-1665.

Hébert, R.F., Link, A.N. (1989). In Search of the Meaning of Entrepreneurship, Small Business Economics 1, 39-49.

Jones, O., Macpherson, A., Jayawarna, D. (2011). Learning to Grow: Dynamic Capabilities in New Technology-based Firms. In Organization Learning and Knowledge Conference. Hull University Business School.

Kirzner, I.M. (1985). The Entrepreneur in Economic Theory, in E. Dahmén, L. Hannah and I. M. Kirzner (eds.) (1994), The Dynamics of Entrepreneurship, Lund: Lund University Press.

Loveman, G., Sengenberger, W. (1991). The Re-Emergence of Small-Scale Production: An International Comparison, Small Business Economics 3, 1-37.

Marshall, A. (1961). Principles of Economics, 9th edition, London: Macmillan.

Porter, M.E. (1990). The Competitive Advantage of Nations, New York: Free Press

Sarasvathy, S.D. (2001). Causation and effectuation: Toward a theoretical shift from economic inevitability to entrepreneurial contingency. Academy of Management Review, 26(2), 243-263.

Schumpeter, J.A. (1934). The Theory of Economic Development, Cambridge, MA: Harvard University. 
Shepherd, D.A., McMullen, J.S., Jennings, P.D. (2007). The formation of opportunity beliefs: overcoming ignorance and reducing doubt. Strategic Entrepreneurship Journal, 1(12), 75-95.

Teece, D.J. (2010). Business Models, Business Strategy and Innovation. Long Range Planning, 43(2-3), 172-194.

Wennekers, S. \& Thurik, R. (1999). Linking Entrepreneurship and Economic Growth, Small PICBE $\mid 710$ Business Economics, 13 (27). 7-55. 